\title{
PENGERTIAN DAN PEMBAGIAN KALAM
}

\author{
Oleh: Muh. Haris Zubaidillah
}

\section{A. Pendahuluan}

Nahwu adalah bagian dari pelajaran bahasa Arab yang berkaitan dengan kedudukan suatu kata. Dengan ilmu ini, insya Allah seseorang akan mampu membaca kitab berbahasa Arab. Namun juga harus ditunjang dengan kaidah-kaidah ilmu shorof.

Ilmu nahwu terbagi menjadi beberapa bagian. Salah satu bagian dari ilmu nahwu yaitu kalam. Dalam makalah ini, kita akan membicarakan tentang pengertian kalam dalam kaidah bahasa Arab dan dilanjutkan dengan pembagian-pembagian kalam. Pembagian-pembagian dari kalam tersebut meliputi kalimat isim, kalimat fi'il, dan kalimat huruf. Dan disertai pembahasan tentang pengertian isim, fi'il, dan huruf.

\section{B. Pengertian Kalam}

Terdapat perbedaan terhadap penyebutan istilah "kata" dalam bahasa Indonesia dan bahasa Arab. Jika dalam bahasa Indonesia disebut "kata", maka dalam bahasa Arab disebut "kalimah". Kumpulan kata dalam bahasa Indonesia disebut "kalimat", sedangkan kumpulan kata dalam bahasa Arab disebut “jumlah".

Bahasa manusia terdiri dari tiga komponen dasar, yaitu:

a. Satuan bunyi disebut "huruf" atau "abjad".

b. Susunan huruf yang memiliki arti tertentu yang dalam bahasa Indonesia disebut "kata" dan dalam bahasa Arab disebut "kalimah". 
c. Rangkaian kata yang mengandung pikiran yang lengkap yang dalam bahasa Indonesia disebut "kalimat" dan dalam bahasa Arab disebut "jumlah".

Kata dalam bahasa Arab disebut dengan istilah kalam/kalimah. Dalam kitab Matn al-Jurumiyah disebutkan bahwasanya al-kalam adalah lafadz yang tersusun dan berfaidah (mempunyai pengertian sempurna dengan disengaja) dalam bahasa Arab. ${ }^{2}$ Sedangkan dalam kitab At-Tuhfatus Saniyyah, al-kalam adalah lafazh yang tersusun yang memberi faidah dengan al-wadh'u (menggunakan bahasa Arab). Lafazh kalam secara bahasa adalah ungkapan yang dengannya dapat menghasilkan suatu faidah. ${ }^{3}$ Adapun kalam dalam ilmu nahwu harus terkumpul 4 perkara, yaitu lafazh, tersusun, memberi faidah, dan sesuai dengan kaidah orang Arab.

\section{a. Lafazh}

Artinya suatu kalam harus ada lafazh, dan yang dimaksud lafazh adalah suara yang mengandung huruf hijaiyah sehingga bisa ditulis dengan huruf hijaiyah, misal

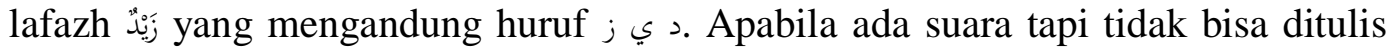
dengan huruf hijaiyah, maka tidak bisa dikatakan sebagai lafazh.

\section{b. Murokkab/Tersusun}

Artinya setelah ada lafazh, maka lafazh itu harus tersusun, minimal tersusun dari 2 kata seperti قَامَ زَيْدُ (Zaid telah beridiri).

\section{c. Mufid/Pengertian Sempurna dan Dengan Disengaja}

Artinya orang yang berbicara telah sempurna diam setelah menyampaikan kalamnya. Suatu ungkapan itu akan dikatakan sebagai kalam apabila ungkapan itu bisa dipahami oleh kedua belah pihak, baik yang berbicara maupun yang

\footnotetext{
${ }^{1}$ Muh Haris Zubaidillah, "Pengantar Ilmu Nahwu Belajar Bahasa Arab Sampai Bisa," h. 1-7, diakses 12 September 2018, https://doi.org/10.31219/osf.io/gm5e7.

${ }^{2}$ Muhammad Ibn Muhammad Ibn Ajurum Ash-Shanhaji, Matn Al-Ajurumiyyah (Surabaya: Al-Haramain, t.t.), h. 1.

3 Muhammad Muhyi ad-Din Abd al-Hamid, At-Tuhfah as-Saniyyah bi Syarh alMuqaddimah al-Ajurumiyyah (Riyadh: Maktabah Dar as-Salam, 1994), h. 1-2.
} 
mendengarkan, misalnya قَامَ زَيْيُ (Zaid telah berdiri). Apabila ada ungkapan yang tersusun dari beberapa kata tetapi maksudnya tidak bisa dipahami oleh yang mendengar maka tidak bisa disebut sebagai kalam, misalnya إِنْ قَامَ زَيٌْْ (jika Zaid قَامَ عُمََّدُ (Muhammad juga berdiri) sehingga menjadi إنْ قَامَ زيُّدُ قَامَ بححَمَّد (jika Zaid berdiri, maka Muhammad juga berdiri). Demikian pula jika ucapan kalam diucapkan dalam keadaan tidak sadar atau tidak dalam keadaan disengaja, maka tidak bisa disebut sebagai kalam.

d. Bil Wadh'i/ Menggunakan Bahasa Arab

Artinya lafazh yang digunakan dalam pembicaraan berupa lafazh-lafazh yang dipakai orang Arab untuk menunjukkan suatu makna. Dengan demikian, ucapan orang 'ajam tidak dapat disebut sebagai kalam. ${ }^{4}$

\section{Pembagian Kalam}

Kalam dibagi menjadi tiga, yaitu:

a. Isim

Isim secara bahasa artinya kata yang menunjukkan yang dinamai. Isim menurut istilah ahli nahwu adalah kata yang menunjukkan suatu makna pada dirinya dan tidak diasosiasikan dengan waktu apapun, contohnya yang menunjukkan kepada manusia, hewan, tumbuhan, benda mati, tempat, waktu, sifat atau makna yang tidak berkaitan dengan waktu.

Tanda isim adalah:

- Dapat ditanwin di akhir kata, contohnya قَمَ;

\footnotetext{
${ }^{4}$ Abu Muhammad Agus Waluyo, "Panduan Praktis Belajar Bahasa Arab Akrab Nahwu," t.t., h. 3, www.akrabnahwu.files.wordpress.com.

${ }^{5}$ Abd al-Hamid, At-Tuhfah as-Saniyyah bi Syarh al-Muqaddimah al-Ajurumiyyah, h. 7.
} 
- Dapat dimasuki oleh ال الكِتَبُ

- Dapat dimasuki oleh huruf nida' (panggilan) pada sebelum kata, contohnya

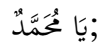

- Dapat dimajrurkan oleh huruf jar sebelum kata, contohnya

- Dapat di-idhofah-kan, contohnya غُسْنْ الشَََّْرَة dan

- Dapat di-isnad ilaih, contohnya

${ }^{6}$ Fu'ad Ni'mah, Mulakhkhash Qawa'id al-Lughah al- 'Arabiyyah (Surabaya: Al- Hidayah, t.t.), h. 17-18. 
Bagi pemula, setidaknya harus memahami pembagian isim sebagai berikut:

1. Isim berdasarkan jumlah (Mufrad, Tasniyah, Jamak)

2. Isim berdasarkan jenis (Mudzakkar dan Muannats)

3. Isim dari segi keumuman dan kekhususan (Ma'rifah dan Nakirah)

4. Isim dari segi penerimaan tanwin (Musharif dan Ghairu Munsharif)

5. Isim ditinjau dari perubahan akhir kata (Mu'rab dan Mabniy) ${ }^{7}$

b. Fi'il

Umumnya fi'il dikenal dalam bahasa Indonesia sebagai kata kerja. Fi'il secara bahasa adalah peristiwa. Adapun fi'il dalam istilah ahli nahwu adalah kata yang menunjukkan suatu makna pada waktu tertentu dari tiga waktu. Tiga waktu itu adalah:

- Fi'il Madhi (lampau), contohnya كَتَب;

- Fi'il Mudhori' (sedang atau akan datang), contohnya يَكْتُبُ dan

- Fi'il Amar (perintah), contohnya

Tanda fi'il adalah:

- Dapat bersambung dengan ta' fa'il, contohnya كَتَبْتُ

- Diakhiri (fi'il madhi) dan diawali (fi'il mudhori') dengan ta' ta'nits, contohnya كَتَكْتُبُ - كَبَتَت

- Dapat bersambung dengan ya' mukhatabah, contohnya أُشْكِرِيْ

- Dapat bersambung dengan nun taukid, contohnya

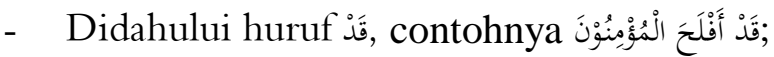

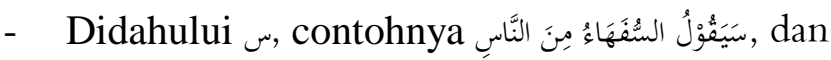

${ }^{7}$ Abu Razin dan Ummu Razin, Ilmu Nahwu Untuk Pemula (Depok: Pustaka BISA, 2015), h. 21, www.programbisa.com.

${ }^{8}$ Abd al-Hamid, At-Tuhfah as-Saniyyah bi Syarh al-Muqaddimah al-Ajurumiyyah, h. 7-8.

${ }^{9}$ Ni'mah, Mulakhkhash Qawa'id al-Lughah al- 'Arabiyyah, h. 20. 


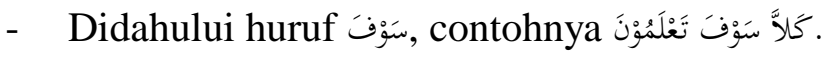

Bagi pemula, setidaknya harus memahami pembagian fi'il sebagai berikut:

1. Fi'il berdasarkan kebutuhan terhadap objek (Fi'il Lazim dan Fi'il Muta'addiy)

2. Fi'il aktif dan pasif (Fi'il Ma'lum dan Fi'il Majhul)

3. Fi'il berdasarkan huruf penyusun (Fi'il Shahih dan Fi'il Mu'tal) ${ }^{10}$

c. Huruf

Huruf adalah setiap kata yang tidak bermakna kecuali jika bersama dengan kata yang lain. ${ }^{11}$ Huruf secara bahasa memiliki arti huruf seperti yang kita kenal dalam bahasa Indonesia yang ada 26 huruf. Sedangkan dalam bahasa Arab kita mengenal 28 huruf yang kita kenal dengan huruf hijaiyah. Akan tetapi, huruf yang dimaksud disini bukan setiap huruf hijaiyah melainkan huruf hijaiyah yang memiliki arti

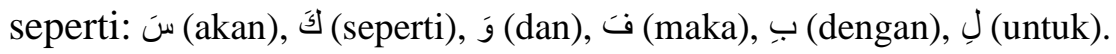

Huruf yang dimaksud disini tidak berarti harus huruf yang disusun dari satu huruf saja, tetapi juga yang disusun dari dua atau lebih huruf yang memiliki makna,

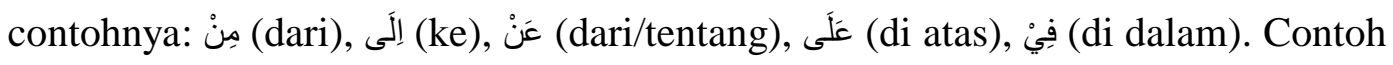

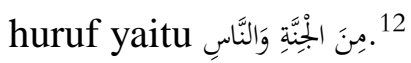

\section{Kesimpulan}

Al-kalam adalah lafadz yang tersusun dan berfaidah (mempunyai pengertian sempurna dengan disengaja) dalam bahasa Arab. Kalam dibagi menjadi tiga, yaitu:

a. Isim, menurut istilah ahli nahwu adalah kata yang menunjukkan suatu makna pada dirinya dan tidak diasosiasikan dengan waktu apapun.

b. Fi'il dalam bahasa Indonesia dikenal dengan istilah kata kerja. Adapun fi'il dalam istilah ahli nahwu adalah kata yang menunjukkan suatu makna pada

\footnotetext{
${ }^{10}$ Razin dan Razin, Ilmu Nahwu Untuk Pemula, h. 12.

${ }^{11}$ Muh. Haris Zubaidillah, Pengantar Ilmu Nahwu Belajar Bahasa Arab Sampai Bisa (Amuntai: Hemat, 2018), h. 7.

${ }^{12}$ Razin dan Razin, Ilmu Nahwu Untuk Pemula, h. 45.
} 
waktu tertentu dari tiga waktu, yaitu lampau (Madhi), sedang atau akan datang (Mudhori'), dan perintah (Amar).

c. Huruf adalah setiap kata yang tidak bermakna kecuali jika bersama dengan kata yang lain. 


\section{DAFTAR PUSTAKA}

Abd al-Hamid, Muhammad Muhyi ad-Din. At-Tuhfah as-Saniyyah bi Syarh alMuqaddimah al-Ajurumiyyah. Riyadh: Maktabah Dar as-Salam, 1994.

Ash-Shanhaji, Muhammad Ibn Muhammad Ibn Ajurum. Matn Al-Ajurumiyyah. Surabaya: Al-Haramain, t.t.

Ni'mah, Fu'ad. Mulakhkhash Qawa'id al-Lughah al-'Arabiyyah. Surabaya: AlHidayah, t.t.

Razin, Abu, dan Ummu Razin. Ilmu Nahwu Untuk Pemula. Depok: Pustaka BISA, 2015. www.programbisa.com.

Waluyo, Abu Muhammad Agus. "Panduan Praktis Belajar Bahasa Arab Akrab Nahwu," t.t. www.akrabnahwu.files.wordpress.com.

Zubaidillah, Muh. Haris. Pengantar Ilmu Nahwu Belajar Bahasa Arab Sampai Bisa. Amuntai: Hemat, 2018.

Zubaidillah, Muh Haris. "Pengantar Ilmu Nahwu Belajar Bahasa Arab Sampai Bisa.” Diakses 12 September 2018. https://doi.org/10.31219/osf.io/gm5e7. 